\title{
Drivers of Sustainability Practices and SMEs: A Systematic Literature Review
}

\author{
Neetu Yadav ${ }^{1}$, Kritesh Gupta ${ }^{2}$, Leela Rani ${ }^{3}$, Deewanshi Rawat ${ }^{4}$
}

\begin{abstract}
Formal SMEs contribute up to $60 \%$ of total employment and up to $40 \%$ of GDP in emerging economies (World Bank, 2015). Globalization council (2009) study reveals that SMEs have more flexibility than MNCs to easily adapt and change to meet important environmental \& social targets. Thus, with the right strategy, SMEs can offer both economic prosperity and environmental protection. This raises an important question as to what drives SMEs to consider sustainability in their practices? The article aims at presenting a comprehensive list of numerous drivers identified globally by various researchers using the research technique of systematic literature review. The study intends to contribute to the knowledge base by providing comprehensive state-of-the-art views and findings in the area sustainability practices and their drivers particularly in the context of SMEs.
\end{abstract}

Keywords: Sustainability Drivers, SMEs, Systematic Literature Review

\section{Introduction}

The consistent pressures from ecology, regulations, customers, and social groups tend businesses to behave responsibly. There are established arguments around the key role of businesses on the road towards environmental sustainability (Sandhu et al., 2010). An increasing investment in CSR activities and advertising, sustainability reporting, mitigation norms, carbon offsetting, etc. are evidence of an increasing awareness of the environmental concerns and sustainability (Moore \& Manring, 2009; Wong et al., 2014). This is generally the case with the large companies who have been proactive in their sustainability efforts, for example, few conglomerate groups such as Tata, Godrej, Mahindra \& Mahindra have shown environmental stewardship in their industries (Nulkar, 2014). However, much research indicates that small-and-medium-sized enterprises (SMEs) are lagging behind (Brammer et al., 2012; Cassells \& Lewis, 2011). However, as SMEs are the backbone of any nation and have a major impact on employment, resource consumption, and pollution, there arises the need to study the sustainability practices of SMEs around the globe, and this article aims to capture prominent drivers, pressures, and motivations of SMEs to adopt sustainability practices.

$\left.\right|^{1}$ Ph.D. (IIT Delhi), Assistant Professor, Department of Management, Birla Institute of Technology and Science, Pilani Campus, Rajasthan, India.

${ }^{2}$ M.B.A. Student, Birla Institute of Technology and Science, Pilani Campus, Rajasthan, India.

${ }^{3}$ Associate Professor, Department of Management, Birla Institute of Technology and Science, Pilani Campus, Rajasthan, India.

${ }^{4}$ Research Associate, Department of Management, Birla Institute of Technology and Science, Pilani Campus, Rajasthan, India. 


\section{SMEs \& Sustainability}

When applied to the corporate world, sustainable development implies the adoption of stratagems and actions that fulfil both the business needs and the current and future societal expectations (Ayuso \& Navarrete-Báez, 2017). The corporate sustainability is a multi-faceted perception having three dimensions: environmental, social, and economic. The economic dimension of sustainability implies that a company having appropriate cash-flow must guarantee liquidity along with a substantial return to stockholders, whereas environmental dimension necessitates the company to have a positive environmental impact by preserving the stability of the environmental system and protecting natural resources. Social dimension encompasses contribution to the community to have a positive social influence through ways of incrementing value to the human capital. Companies should implement an all-inclusive purview of sustainability in approaches, as an accomplishment in a single of these dimensions will not help in longterm sustainability (Günerergin et al., 2012).

SMEs are considered as Small and Medium Enterprises but their collective contribution in this world is very high, and they are the vertebrae of economic growth worldwide. According to the International Finance Corporation, more than 90 per cent of companies globally are SMEs, accounting for more than half of all employment (Gandhi et al., 2018; Shields \& Shelleman, 2015). OECD recognises SMEs contribution to be $60 \%$ of the EU's GDP and is an important source of wealth formation and innovation (Williamson et al., 2006). They have a great collective impact, especially so in a country of small businesses like New Zealand, in which $98 \%$ of all businesses comprise of SMEs (Lawrence et al. , 2006). In the Asian region, according to TUIK.org (2008), there were over 2.5 million SMEs which account for $99.8 \%$ of all Turkish businesses (Agan et al., 2013). Chinese SMEs perform an expanding role in sustainability adoption, accounting for $99 \%$ of the country's businesses, $60 \%$ of exports, $40 \%$ of GDP and $75 \%$ of job opportunities (Lee \& Klassen, 2008; Yu, 2007). In Indian perspective, it offers employment to over 80 million public in almost 36 million MSME units, contributes about 8 per cent to Indian GDP, produces more than 6,000 products, accounts for 45 $\%$ t of total manufacturing output and $40 \%$ of the nation's export (Roy et al., 2013).

A lot of firms have boarded on sustainability initiatives addressing social, corporate and environmental matters, but the concept of sustainability remains unidentified amongst SMEs (Yu, 2007). Despite their important role, many SMEs have shown petite curiosity in ecological matters and usually lack tools and means for assimilating ecological work under their environmental actions. They have less information about managing the environment and do not appreciate this idea and are unable to see the link between environmental management system, and its benefits (Aghelie, 2017; Musa \& Chinniah, 2016). The collective impact of SMEs on the ecological environment is considerable and could offset the total impact of large firms (Musa \& Chinniah, 2016; Wattanapinyo \& Mol, 2013). It is estimated that about $60-70 \%$ of total pollution is because of SMEs (Hoogendoorn et al., 2015; Johnson, 2015). In 2002, the EC projected that among EU countries, SMEs were accountable for half of the waste and pollution. In the UK, the Environment Agency concluded that SMEs are accountable for around 80\% of pollution and almost $60 \%$ of commercial waste (Halila, 2007; Revell et al., 2010). SMEs, especially 
within manufacturing sectors, account for 64\% of air pollution whereas only a small portion of $0.4 \%$ of these SMEs complies with an environmental management system (Behjati, 2017).

The above facts make clear that sustainability practices need to be taken seriously among SMEs. Pioneering researchers have called for further consideration to be done to studies related to SMEs contribution to sustainability. The relative silence as compared to large industries in extant research on environment management within SMEs is worrying specified their overall significance in most of the economies (Brammer et al., 2012).

\section{Methodology Used: Systematic Literature Review}

A systematic literature review (SLR) is about "synthesizing research in a reproducible, transparent, and systematic manner" (Tranfield et al., 2003). This review generally consists of three distinct steps of planning, where prerequisite of the research and question is first recognised; conducting that comprises the exploration for appropriate literature and its analysis, and reporting in which the discoveries are formalised, and recommendations are made (Ashby et al., 2012). The goal of the SLR is the provision of collective insights via theoretical synthesis. Its rigorous methodology helps in building a reliable knowledge base and developing a set of 'field tested and ground technological rules.' Thus it can be said to be a pragmatic management research tool, which aims to serve both academic and practitioner communities (Tranfield et al., 2003).

There have been few studies based on SLR which are linked to sustainability and SMEs. To improve the methodological rigorousness of reviews of management, Gast et al. (2017) followed SLR to consolidate literature in the field of sustainable ecological entrepreneurship and identified drivers of engagement in sustainable entrepreneurship and provided an integrative framework. Pacheco et al. (2017) carried out a systematic review of the last 24 years literature to develop a solid knowledge base to help in identifying the determinants of ecological innovation in SMEs and related strategies. Bossle et al. (2016) applied SLR for identifying main drivers \& motivation for adoption of ecological innovation because of its specificity related to the research question.

This article has followed the methodology adopted by Klewitz \& Hansen (2014), which talks about the SLR of the sustainability orientated innovation (SOI) of SMEs. It focuses on the innovation practices including different types of SOIs and strategic sustainability behaviours of SMEs through an interdisciplinary, SLR from diverse fields such as environmental and sustainability management, innovation management, and SME research, in a time-frame between 1987 and 2010.

\section{Identification of drivers of sustainability practices using a systematic literature review}

The goal of this systematic review is to streamline the research arena on drivers of sustainability practices in the framework of SMEs, recognise emergent themes, indicate most important gaps, and thus contribute to theory development (Klewitz \& Hansen, 2014). A systematic review includes bibliographical, quantitative analysis, and a more qualitative thematic analysis (Tranfield et al., 2003). The study follows the process 
used in the study by Klewitz and Hansen (2014) where the six-steps process has been used that is illustrated in Table 1. The description of these steps is presented below:

Table 1: Steps of systematic literature review

\begin{tabular}{|c|c|c|c|}
\hline $\begin{array}{l}\text { Overall } \\
\text { process }\end{array}$ & Individual steps & Analysis & $\begin{array}{l}\text { Resulting in } \\
\text { no. of articles }\end{array}$ \\
\hline \multirow{2}{*}{$\begin{array}{l}\text { Search } \\
\text { process }\end{array}$} & $\begin{array}{l}\text { Step 1: Identification of keywords }(25 \\
\text { keywords) } \\
\text { Step 2: Development of exclusion and } \\
\text { inclusion criteria } \\
\text { Step 3: Specification of relevant search } \\
\text { engines and execution of search ( } 5 \text { engines) }\end{array}$ & $\begin{array}{l}\text { Previous research } \\
\text { and reviews } \\
\text { Title and abstracts } \\
\text { (automated based } \\
\text { on keywords) }\end{array}$ & 733 \\
\hline & $\begin{array}{l}\text { Step 4: Development of A, B, and C list } \\
\text { C-list } \\
\text { B-list } \\
\text { A-list }\end{array}$ & $\begin{array}{l}\text { Title \& abstract } \\
\text { (manual) } \\
\text { Full-Text }\end{array}$ & $\begin{array}{l}733 \\
101 \\
44\end{array}$ \\
\hline $\begin{array}{l}\text { Descriptive } \\
\text { and Thematic } \\
\text { Analysis }\end{array}$ & $\begin{array}{l}\text { Step 5: Descriptive categories (e.g. journals } \\
\text { covered, year of publication, countries } \\
\text { covered) } \\
\text { Step 6: Deductive and inductive categories to } \\
\text { identify central themes and interpret results }\end{array}$ & & 44 \\
\hline
\end{tabular}

\section{Step 1: Identification of keywords}

To cover all kinds of literature available, three groups of keywords were developed based on the various interpretation of the three words- SMEs, sustainability practices and drivers. Some of these are- small firms, medium-sized firms, etc. for SMEs; green practices, environmental practices, pro-environment practices, environment-friendly practices, etc. for sustainability practices; and pressures, motivators, factors, etc. for drivers (Table 2). Overall, a total of 25 keywords were used for the search, and targeted articles were required to have at least one keyword out of these.

Table 2: List of keywords

\begin{tabular}{|c|c|c|}
\hline SMEs & $\begin{array}{l}\text { Sustainability } \\
\text { practices }\end{array}$ & Drivers \\
\hline SMEs & Sustainability practices & Drivers \\
\hline Small firms & Green practices & Pressures \\
\hline Small businesses & Pro-environmental & Motivators \\
\hline Small companies & practices & Influencers \\
\hline Medium-size firms & Environmental & Factors \\
\hline Medium-size companies & practices & Reasons \\
\hline Medium size businesses & Environmental & behaviours \\
\hline Small and & management & considered under drivers for sustainability \\
\hline firms/business/companies & $\begin{array}{l}\text { Corporate social } \\
\text { responsibility practices } \\
\text { Ecological practices } \\
\text { Sustainability trends }\end{array}$ & practices \\
\hline
\end{tabular}

\section{Step 2: Development of exclusion and inclusion criteria}

Two criterions were decided- published literature should be from a peer-reviewed journal, and it should be within the time frame of 1987-2018. Though systematic reviews can also include a different kind of publications, Klewitz and Hansen (2014) argue, 
quality can be guaranteed, and size could be reduced to manageable size via concentration on peer-reviewed academic journal papers in the English language as done by other scholars and researchers. The decision for the specific time frame was made because the concept of sustainability has gained worldwide popularity since the publication of the Brundtland report "Our Common Future" in 1987.

Steps 3 and 4: Searching in research databases and development of $A, B$, and $C$ lists

This review includes the following major research databases: EBSCO, EMERALD, Science Direct, Scopus, and Wiley Online. The scope of these databases supported our aim of covering literature from all aspects of environmental management by an SME. Each database and linked search engines work with different syntax, and thus adapted search strings were necessary in various cases. The three key terms which were the basis of groupings of words were searched on all databases. Initially, we began with a database of 733 articles which we categorised into A (most relevant), B (less relevant), and C (not relevant). The initial C-list of 733 articles was reduced to 101 relevant articles (B-list) based on the title and abstract analysis. This B-list was analysed in-depth (title, abstract, full text) in an iterative process, which led to the elimination and addition of articles to arrive at the A-list. Those articles from the references of B-list articles which had a clear focus on drivers and sustainability practices were also included in this step. The most obvious reasons for eliminating articles from the B-list include lack of focus on SME, on drivers of sustainability practices, and on the environment. The final A list comprised of 44 articles were taken further for descriptive and thematic analysis.

\section{Step 5: Descriptive Analysis}

For the descriptive analysis, those categories were selected that describe the papers regarding methods applied, journals covered, etc. (Klewitz \& Hansen, 2014).

\section{Step 6: Thematic Analysis}

For the thematic analysis, NVivo software was used to develop themes linked to drivers of sustainability practices. The themes were formalised as they emerged after the coding process involved in the analysis and were inductively derived from the full-text analysis of articles in the A-List. After coding, systematic categorisation of the content was done to identify the emergent drivers. The results are organised into two parts. First, we present a quantitative descriptive (bibliographical) analysis of an outline of the research schema on drivers of sustainability practices in SMEs. Second, we present a qualitative thematic analysis to provide an in-depth analysis of the drivers.

\section{Results}

The A-List was analysed using NVivo for descriptive and thematic analysis, the result of which are detailed below:

\section{Descriptive Analysis}

The most important journals for sustainability drivers in SMEs- where the maximum number of articles were published- are those with a focus on sustainability or environment, with the CSR and environmental management taking a dominant role. (Figure 1). In the 44 articles, the most important source of empirical evidence in the sample is based on surveys which include questionnaire surveys, face-to-face interviews, 
expert interviews, and telephonic interviews approaches. Further, qualitative studies used case study methods (6 articles) and literature reviews (2 articles).

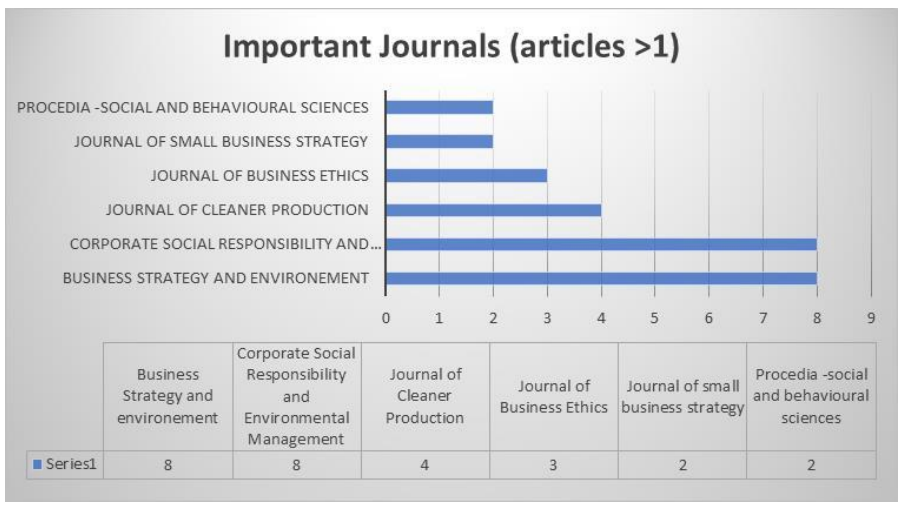

Figure 1: Important Journals

As far as the focus of the articles is concerned, the studies had targeted diverse countries across the globe covering regions of North America, Europe, Africa, and Asia. The most dominated region was Europe in which 15 studies were published. The South Asian region was prominent amongst the Asian regions. There are some studies which focused only on single countries. The research on drivers of sustainability practices of SMEs has gained momentum lately is evident from the fact that more number of papers were published post- 2009. Out of 44 articles, almost $66 \%$ are published post-2010 with a maximum in the year of 2015, a year preceding the Paris Climate Change Conference, 2016 (Figure 2).

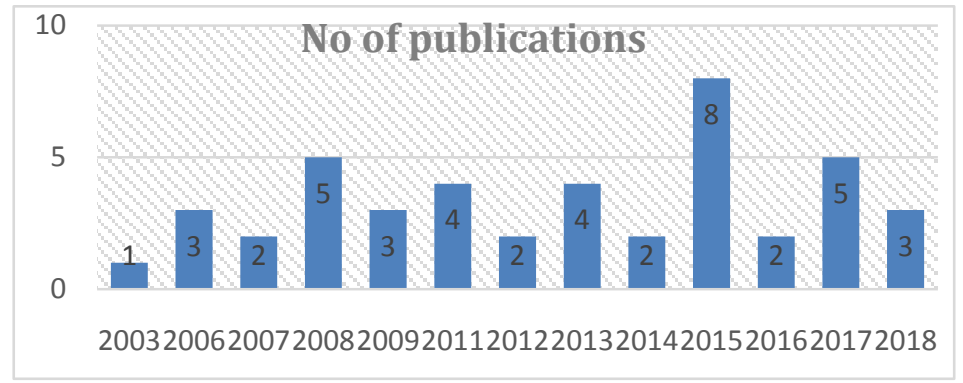

Figure 2: Time Frame of Publications

\section{Thematic Analysis}

The thematic analysis is done to identify essential drivers associated with sustainable practices in an SME context. Two major building blocks that emerged are external and internal drivers. Sub-coding was done on each of these drivers to find out their constituents. A detailed description of identified drivers, under each heading, is presented below (also see figure 3).

\section{External Drivers}

The external drivers are critical reasons for SMEs to inculcate sustainability practices; Studer's (2006) research indicated that in the absence of external pressure most of the SMEs are unwilling for environmental engagement. The current study found two main 
external drivers- stakeholders, and tangibility of the business sector of the SMEs. The Stakeholders include Government, customers, networks and alliances, suppliers, communities, and competitors. Here, is a brief description of each of these:

\section{Government}

Government is found to be a major external driver which influences the behavior of SMEs primarily through regulation, legislation, economic and structural support, and knowledge dissemination. Gandhi et al. (2018) research findings explain that support of the Government is extremely significant for a successful deployment of lean-green paradigms. Cambra-Fierro and Ruiz-Benítez (2011) say that the sustainable practices are primarily motivated by legislation. Zhang et al. (2009) write, "Regulation may be the most appropriate mechanism to improve the environmental performance of small firms". High fines and penalties, in case of noncompliance with regulations forces SMEs to adopt sustainable practices (Sáez-Martínez et al., 2016). Along with the legislation and regulation, incentives in the form of loans, grants, tax concessions and other economic benefits facilitate easy adoption and behavioral change in SMEs towards sustainable practices (Gandhi et al., 2018; Revell et al., 2010).

\section{Customers}

Existing studies provide much evidence that customers influence the behaviour of SMEs towards sustainability through green demand, compliance-driven demand, and the dynamics of buyer's organisations. It has been strongly argued from different scholars that the proactive demand of green products, processes, and services leads to the development of environmental practices in SMEs (Battisti \& Perry, 2011; Lee, 2009; Sáez-Martínez et al., 2016; Shields \& Shelleman, 2015; Studer et al., 2006). Spurred by buyers' support, many SME suppliers have undertaken improvement initiatives that lead to efficient energy and resource management and reduced their footprints (Lee \& Klassen, 2008). Few works have mentioned that buyers are demanding that the SMEs should have ISO 14001 certification to be a recognised supplier (Gadenne et al., 2009; Günerergin et al., 2012; Lee \& Klassen, 2008).

\section{Network and Alliances}

The SMEs owners and managers show a positive attitude towards networks in local business and environmental agencies which play an important role in building cooperative relationship and trust needed for collective actions to solve ecological problems (Revell, 2010). SMEs are appositively impacted by dissemination of knowledge on environmental practices and cost-benefit advantages (Gadenne, 2009).

\section{Suppliers}

Lee (2008) argues that SMEs have participated in greening supply chain depending on their supplier's readiness. The inclusion of green procurement policies and environmental criteria by SMEs into their supplier selections have created a significant change (Lee \& Klassen, 2008). In case of China, supply chain pressure existed more for those SMEs who had internationalised their operations rather than domestic ones; the former ones presented an improved social or environmental performance and motivation towards sustainable practice (Yu, 2007). Ghadge et al. (2017) highlight that 
suppliers are a significant driving force for the SMEs in their motivation to green the supply chain networks in the Greek dairy industry.

\section{Community Surrounding}

The community is a major motivation for SMEs in various countries to adopt sustainable practices. In Australia, the environmental pressure groups were one of the major forces that made SMEs take up environmental sustainability in their practices (Williams \& O'Donovan, 2015). In the case of China, raised environmental awareness and demands of the local community pressurised SMEs to promote environmental practices performance (Zhang et al., 2009). A public demand emerged as a second major driver for sustainability practices among SMEs in the UK in the work of Jansson et al. (2017). Civil society agencies and institutions had helped Thailand's agro-based SMEs to improve environmental performance (Wattanapinyo \& Mol, 2013). In Indian scenario, local administrations, media, local communities, and NGOs were among top 15 drivers for adoption of green manufacturing practices in Indian SMEs as per the study by Gandhi et al. (2018).

\section{Competitors}

Lee and Klassen (2008) say that the suppliers change the materials in their products after studying the new trends about products of their competitors in worldwide markets to establish objectives for greater recyclability, formal procedures for the environmental performance of their new product development processes and introduces environmental safety and recyclability as criteria for product performance. In a particular case of Italy, it was found that the competitor's behaviour drove the SMEs to adopt environmental management practices as they did not have internal abilities to interpret market dynamics (Testa et al., 2016).

\section{Tangibility aspect of the business sector}

So far, we have discussed various stakeholders as the drivers of sustainability practices in SMEs. However, it should be noted that the environmental practices of the SMEs also depend upon tangibility of the sector in which they operate. Tangibility here refers to products and services offered by SMEs. As per Uhlaner et al. (2012), the tangibility of business sector has a great effect on adoption of green practices; greater the tangibility of the sector, more the SMEs will introduce the environmental practices in their system. A study by Hoogendoorn (2015) showed that SMEs are more dedicated to implementing pro-environment processes and offer green products \& services in high tangibility sectors. 


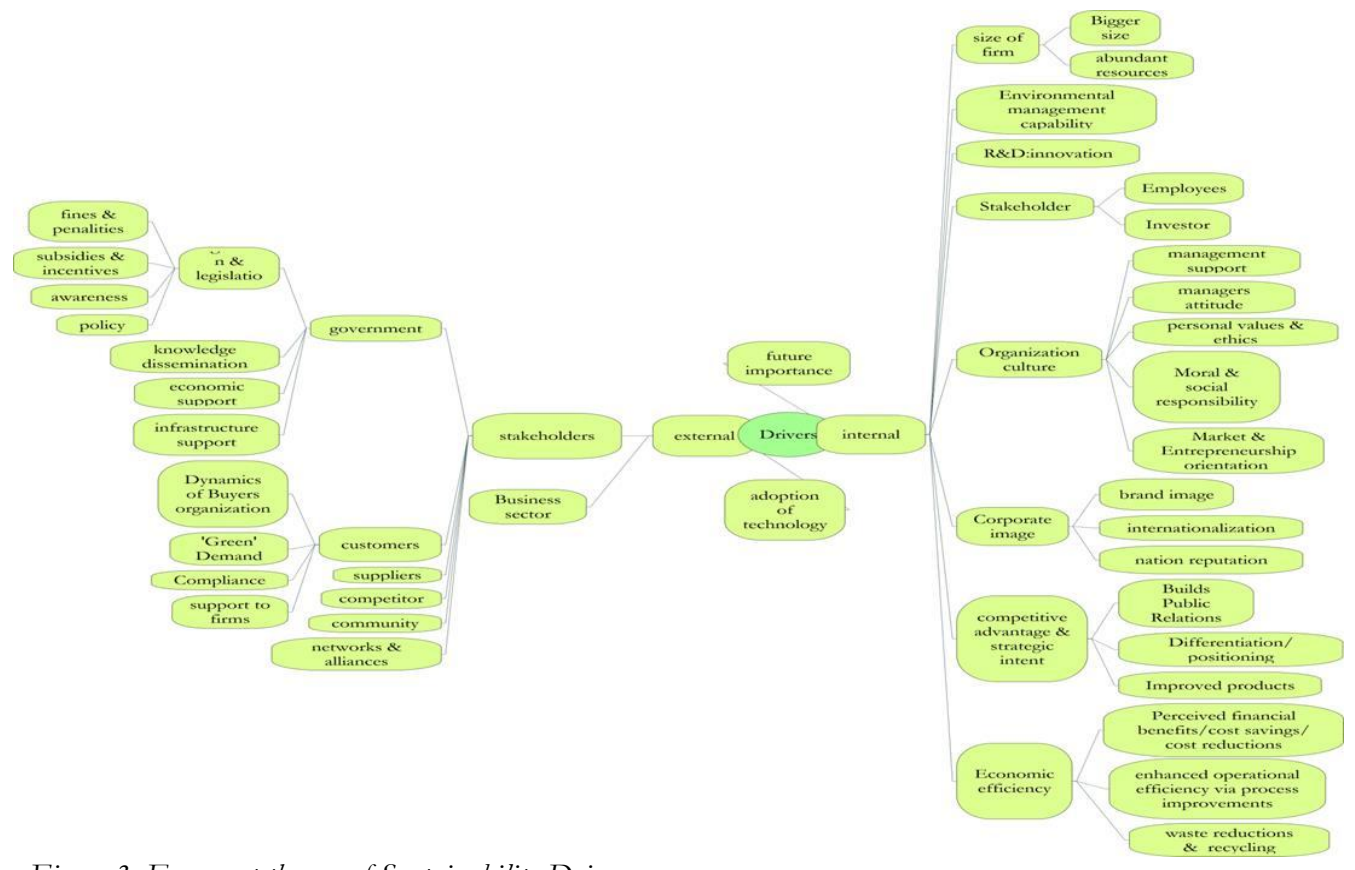

Figure 3: Emergent themes of Sustainability Drivers

\section{Internal drivers}

Another set of drivers that impact the sustainability practice of SMEs are internal drivers. They comprise of employees, organisation culture, brand image and reputation, competitive advantage and strategic intent, environment management capability, and size of the firm. Here, is the brief description of each of these.

\section{Employees}

The employees are found to be influencing SMEs in their orientation towards sustainability. Zhang (2009) writes that one of the crucial factors in promoting SMEs to adopt environmental practices is the demand from employees. Masurel (2007) highlights that working conditions for employees is the most important motivation for SMEs to invest in ecological measures. Some SMEs identify that in Greek food supply chain, investors impact environmental performance of SMEs by influencing their decisions via raising environmental consciousness (Ghadge et al., 2017). Uhlaner et al. (2012) say that family stakeholders in SMEs pressurise for pro-environment practices as they want to maintain their reputation for the company as well as family too.

\section{Organization culture}

It includes personal values and ethics of owners and managers, moral and social responsibility, management support, and knowledge management. The company's values drive corporate environmental responsibility in SMEs. As per Font (2016), habit and lifestyle of SME owners affect sustainability activities in SMEs. The personal commitment of managers of SMEs for pro-environmental attitude was key to their performance (Koe et al., 2015). SMEs perceive environmental sustainability as their moral and social responsibility towards their stakeholders as well as the natural environment (Wahga et al., 2017). As per Gandhi (2018), 'top management commitment' 
is the most critical driver in the successful implementation of Lean Manufacturing and Green Manufacturing practices. The social responsibility and ethical concerns of the top managers drive environmental practices Johnson, 2015; Lee, 2009; Shields \& Shelleman, 2015; Thanki \& Thakkar, 2018). Organizational culture is one of the major drivers towards sustainability practices in SMEs (Cambra-Fierro \& Ruiz-Benítez, 2011; Ghadge et al., 2017; Uhlaner et al., 2012; Wahga et al., 2017).

\section{Brand image and reputation}

Many researchers consider corporate image to be a key driver for environmental performance of SMEs (Agan et al., 2013; Battisti \& Perry, 2011; Gadenne et al., 2009; Ghazilla et al., 2015; Masurel, 2007; Sáez-Martínez et al., 2016; Studer et al., 2006; Yu, 2007). Social capital drives SMEs and thereby improving their reputation as an ecologically responsible firm in the market for economic gains, legitimising their existence, attracting customers, increasing their sales, and satisfying their external stakeholders (Wahga et al., 2017; Font et al., 2016). SMEs wish to improve their green public image, demonstrate environmental stewardship, and green brand image via environmental activities (Battisti \& Perry, 2011; Cambra-Fierro \& Ruiz- Benítez, 2011; Gandhi et al., 2018; Lee, 2009; Revell et al., 2010; Roy et al., 2013).

\section{Competitive advantage and strategic intent}

Gadenne (2009) found that SME managers could undertake sustainability practices in their economic self-interest. The multitude of benefits regarding cost reduction, waste reduction, recycling, differentiation, etc. provides a competitive advantage to SMEs which motivates them to adopt sustainability actions (Battisti \& Perry, 2011; Font et al., 2016; Gadenne et al., 2009; Lee, 2009). Incentives such as long-run financial and market position payoffs acted as a strategic motivator for medium-sized firms to environmental engagement (Jansson et al., 2017).

\section{Environmental Management Capability (EMC)}

The environmental management capabilities (assets, skills, and technologies) support the SME to respond more decisively and timely to several environmental demands of stakeholders. SMEs with greater environmental experience, i.e. development of internal environmental management capabilities within them leads to better and proactive response towards sustainability practices related to organisational performance (SáezMartínez et al., 2016). The robust resource base is an important capability for environmental practice (Shields \& Shelleman, 2015). As per Thanki \& Thakkar (2018), the organisational capability is a crucial critical success factor for enhancing environmental and operations performances of SMEs leading to sustainability.

\section{Size of firm}

As per Reyes-Rodríguez et al. (2016) research, size of the firm has turned out to be a significant motivator for environmental performance of SMEs. Medium-sized firms both regarding employees and turnover are more engaged in greener practices (Hoogendoorn et al., 2015). Sustainability management tools are implemented in SMEs with larger organisational size along with the positive perception of relative advantage over previous practices (Johnson, 2015). 


\section{Discussions}

As per the above analysis it could be seen there are various drivers which could be clubbed into themes and sub-themes. There has been evidence of external \& internal drivers being major drivers or being secondary drivers in the research papers used in the thematic analysis. Apart from these drivers, there were certain categories which could not be clubbed into these two blocks such as future importance, adoption of advanced technology, etc. Lawrence (2006), K. Lee (2009) and Gandhi (2018) highlighted the fact that SMEs based on the future importance of environmental practices as a key success factor make a move towards them. Zhang (2009), Aboelmaged (2018), Gandhi et al. (2018), and Hofmann et al. (2012) explored the importance of technological upgradation of SMEs so that they could be driven towards sustainable practices that will enhance their operational efficiency as well as profits. It is interesting to note that apart from drivers, there are certain barriers \& constraints too in the implementation of sustainable practices in SMEs like the dearth of time, lack of financial resources, the perception of nil impact on the environment, low environmental awareness, weaker governmental regulation and culture too. All in all, the drivers would depend upon the context of operations of SMEs, i.e. in which sector they lie, external stakeholders in the country of operation etc. It is up to SMEs whether they want to join this collaborative effort or stick to their business as usual behaviour. This article contributes to the knowledge base of sustainability research by providing a comprehensive list of crucial drivers of sustainability practices in SMEs context.

\section{Acknowledgement}

The authors are thankful to ICSSR for its financial support in this research.

\section{References}

Aboelmaged, M. (2018). The drivers of sustainable manufacturing practices in Egyptian SMEs and their impact on competitive capabilities: A PLS-SEM model. Journal of Cleaner Production, 175, $207-221$. https://doi.org/10.1016/j.jclepro.2017.12.053

Agan, Y., Acar, M. F., \& Borodin, A. (2013). Drivers of environmental processes and their impact on performance: A study of Turkish SMEs. Journal of Cleaner Production, 51, 23-33. https://doi.org/10.1016/j.jclepro.2012.12.043

Aghelie, A. (2017). Exploring drivers and barriers to sustainability green business practices within small medium sized enterprises : primary findings, 5(1), 41-48.

Ashby, A., Leat, M., \& Hudson-Smith, M. (2012). Making connections: a review of supply chain management and sustainability literature. Supply Chain Management: An International Journal, 17(5), 497-516. https://doi.org/10.1108/13598541211258573

Ayuso, S., \& Navarrete-Báez, F. E. (2017). How Does Entrepreneurial and International Orientation Influence SMEs' Commitment to Sustainable Development? Empirical Evidence from Spain and Mexico. Corporate Social Responsibility and Environmental Management. https://doi.org/10.1002/csr.1441

Battisti, M., \& Perry, M. (2011). Walking the talk? Environmental responsibility from the perspective of small-business owners. Corporate Social Responsibility and Environmental Management, 18(3), 172-185. https://doi.org/10.1002/csr.266

Behjati, B. S. (2017). Critical Remarks about Environmentalism Implication by Iranian SMEs, $209-219$. https://doi.org/10.14207/ejsd.2017.v6n3p209 
Bossle, M. B., Dutra De Barcellos, M., Vieira, L. M., \& Sauvée, L. (2016). The drivers for adoption of ecoinnovation. Journal of Cleaner Production, 113, 861-872. https://doi.org/10.1016/j.jclepro.2015.11.033

Brammer, S., Hoejmose, S., \& Marchant, K. (2012). Environmental Management in SMEs in the UK: Practices, Pressures and Perceived Benefits. Business Strategy and the Environment, 21(7), 423-434. https://doi.org/10.1002/bse.717

Cambra-Fierro, J., \& Ruiz-Benítez, R. (2011). Sustainable business practices in Spain: a two-case study. European Business Review, 23(4), 401-412. https://doi.org/10.1108/09555341111145780

Cassells, S., \& Lewis, K. (2011). SMEs and Environmental Responsibility: Do Actions Refl ect Attitudes? Corporate Social Responsibility and Environmental Management, 199(3), 186-199. https://doi.org/10.1002/csr

Chassé, S., \& Courrent, J.-M. (2017). Linking owner-managers' personal sustainability behaviors and corporate practices in SMEs: The moderating roles of perceived advantages and environmental hostility. Business Ethics: A European Review, (March). https://doi.org/10.1111/beer.12176

Font, X., Garay, L., \& Jones, S. (2016). Sustainability motivations and practices in small tourism enterprises in European protected areas. Journal of Cleaner Production, 137, 1439-1448. https://doi.org/10.1016/j.jclepro.2014.01.071

Gadenne, D. L., Kennedy, J., \& McKeiver, C. (2009). An empirical study of environmental awareness and practices in SMEs. Journal of Business Ethics, 84(1), 45-63. https://doi.org/10.1007/s10551-0089672-9

Gandhi, N. S., Thanki, S. J., \& Thakkar, J. J. (2018). Ranking of drivers for integrated lean-green manufacturing for Indian manufacturing SMEs. Journal of Cleaner Production (Vol. 171). Elsevier B.V. https://doi.org/10.1016/j.jclepro.2017.10.041

Gast, J., Gundolf, K., \& Cesinger, B. (2017). Doing business in a green way: A systematic review of the ecological sustainability entrepreneurship literature and future research directions. Journal of Cleaner Production, 147, 44-56. https://doi.org/10.1016/j.jclepro.2017.01.065

Ghadge, A., Kaklamanou, M., Choudhary, S., \& Bourlakis, M. (2017). Implementing environmental practices within the Greek dairy supply chain. Industrial Management \& Data Systems, 117(9), 1995-2014. https://doi.org/10.1108/IMDS-07-2016-0270

Ghazilla, R. A. R., Sakundarini, N., Abdul-Rashid, S. H., Ayub, N. S., Olugu, E. U., \& Musa, S. N. (2015). Drivers and barriers analysis for green manufacturing practices in Malaysian smes: A preliminary findings. Procedia CIRP, 26, 658-663. https://doi.org/10.1016/j.procir.2015.02.085

Gimenez, C., \& Tachizawa, E. M. (2012). Extending sustainability to suppliers: a systematic literature review. Supply Chain Management: An International Journal, 17(5), 531-543. https://doi.org/10.1108/13598541211258591

Günerergin, M., Penbek, Ş., \& Zaptçığlu, D. (2012). Exploring the Problems and Advantages of Turkish SMEs for Sustainability. Procedia - Social and Behavioral Sciences, 58, 244-251. https://doi.org/10.1016/j.sbspro.2012.09.998

Halila, F. (2007). Networks as a means of supporting the adoption of orgnaizational innovation in SMEs: The case of environmental management systems (EMSs) based on ISO 14001. Corporate Social Responsibility and Environmental Management, 14(September 2006), 167-181.

Harrington, D., Walsh, M., Owens, E., Joyner, D. J., Griffiths, G., Doyle, E., ... Lynch, P. (2016). University Partnerships for International Development Article information:

Hofmann, K. H., Theyel, G., \& Wood, C. H. (2012). Identifying Firm Capabilities as Drivers of Environmental Management and Sustainability Practices - Evidence from Small and MediumSized Manufacturers. Business Strategy and the Environment, 21(8), 530-545. https://doi.org/10.1002/bse.739

Hoogendoorn, B., Guerra, D., \& van der Zwan, P. (2015). What drives environmental practices of SMEs? Small Business Economics, 44(4), 759-781. https://doi.org/10.1007/s11187-014-9618-9

Jansson, J., Nilsson, J., Modig, F., \& Hed Vall, G. (2017). Commitment to Sustainability in Small and Medium-Sized Enterprises: The Influence of Strategic Orientations and Management Values. Business Strategy and the Environment, 26(1), 69-83. https://doi.org/10.1002/bse.1901

Johnson, M. P. (2015). Sustainability Management and Small and Medium-Sized Enterprises: Managers' Awareness and Implementation of Innovative Tools. Corporate Social Responsibility and Environmental Management, 22(5), 271-285. https://doi.org/10.1002/csr.1343 
Klewitz, J., \& Hansen, E. G. (2014). Sustainability-oriented innovation of SMEs: A systematic review. Journal of Cleaner Production, 65, 57-75. https://doi.org/10.1016/j.jclepro.2013.07.017

Koe, W.-L., Omar, R., \& Majid, I. A. (2014). Factors Associated with Propensity for Sustainable Entrepreneurship. Procedia - Social and Behavioral Sciences, 130, 65-74. https://doi.org/10.1016/j.sbspro.2014.04.009

Koe, W.-L., Omar, R., \& Sa'ari, J. R. (2015). Factors Influencing Propensity to Sustainable Entrepreneurship of SMEs in Malaysia. Procedia - Social and Behavioral Sciences, 172, 570-577. https://doi.org/10.1016/j.sbspro.2015.01.404

Lawrence, S. R., Collins, E., Pavlovich, K., \& Arunachalam, M. (2006). Sustainability Practices of SMEs : th e Case of NZ. Business Strategy and the Environment, 15(4), 242-257.

Lee, K. (2009). Why and how to adopt green management into business organizations? Management Decision, 47(7), 1101-1121. https://doi.org/10.1108/00251740910978322

Lee, S. (2008). Drivers for the participation of small and medium-sized suppliers in green supply chain initiatives. Supply Chain Management: An International Journal, 13(3), 185-198. https://doi.org/10.1108/13598540810871235

Lee, S. Y., \& Klassen, R. D. (2008). Drivers and enablers that foster environmental management capabilities in small- and medium-sized suppliers in supply chains. Production and Operations Management, 17(6), 573-586. https://doi.org/10.3401/poms.1080.0063

Masurel, E. (2007). Why SMEs invest in environmental measures: Sustainability evidence from small and medium-sized printing firms. Business Strategy and the Environment, 16(3), 190-201. https://doi.org/10.1002/bse.478

Musa, H., \& Chinniah, M. (2016). Malaysian SMEs Development: Future and Challenges on Going Green. Procedia - Social and Behavioral Sciences, 224(August 2015), 254-262. https://doi.org/10.1016/j.sbspro.2016.05.457

Nulkar, G. (2014). SMEs and Environmental Performance - A Framework for Green Business Strategies. Procedia - Social and Behavioral Sciences, 133, 130-140. https://doi.org/10.1016/j.sbspro.2014.04.177

Pacheco, D. A. de J., ten Caten, C. S., Jung, C. F., Ribeiro, J. L. D., Navas, H. V. G., \& Cruz-Machado, V. A. (2017). Eco-innovation determinants in manufacturing SMEs: Systematic review and research directions. Journal of Cleaner Production, 142, 2277-2287. https://doi.org/10.1016/j.jclepro.2016.11.049

Perez-Sanchez, D., \& Barton, J. (2003). Implementing environmental management in SMEs. Management, 77 , 67-77. Retrieved from http://onlinelibrary.wiley.com/doi/10.1002/csr.37/full

Revell, A., Stokes, D., \& Chen, H. (2010). Small businesses and the environment:Turning over a new leaf? Business Strategy and the Environment, 19(5), 273-288. https://doi.org/10.1002/bse.628

Reyes-Rodríguez, J. F., Ulhøi, J. P., \& Madsen, H. (2016). Corporate Environmental Sustainability in Danish SMEs: A Longitudinal Study of Motivators, Initiatives, and Strategic Effects. Corporate Social Responsibility and Environmental Management, 23(4), 193-212. https://doi.org/10.1002/csr.1359

Rodger, C. (2010). Sustainable entrepreneurship in SMEs: a case study analysis. Corporate Social Responsibility and Environmental Management, 17(3), 125-132.

Roy, M., Boiral, O., \& Paillé, P. (2013). Pursuing quality and environmental performance. Business Process Management Journal, 19(1), 30-53. https://doi.org/10.1108/14637151311294859

Sáez-Martínez, F. J., Díaz-García, C., \& González-Moreno, Á. (2016). Factors promoting environmental responsibility in European SMEs: The effect on performance. Sustainability (Switzerland), 8(9). https://doi.org/10.3390/su8090898

Shields, J., \& Shelleman, J. M. (2015). No Title.

Studer, S., Welford, R., \& Hills, P. (2006). in Environmental Change: Drivers and Barriers, 431(March), 416-431.

Testa, F., Gusmerottia, N. M., Corsini, F., Passetti, E., \& Iraldo, F. (2016). Factors Affecting Environmental Management by Small and Micro Firms: The Importance of Entrepreneurs' Attitudes and Environmental Investment. Corporate Social Responsibility and Environmental Management, 23(6), 373385. https://doi.org/10.1002/csr.1382

Thanki, S. J., \& Thakkar, J. (2018). Interdependence analysis of lean-green implementation challenges: A case of Indian SMEs. Journal of Manufacturing Technology Management. https://doi.org/10.1108/JMTM-04-20170067 
Tranfield, D., Denyer, D., \& Smart, P. (2003). Towards a Methodology for Developing Evidence-Informed Management Knowledge by Means of Systematic Review. British Journal of Management, 14(3), 207222. https://doi.org/10.1111/1467-8551.00375

Uhlaner, L. M., Berent-Braun, M. M., Jeurissen, R. J. M., \& de Wit, G. (2012). Beyond Size: Predicting Engagement in Environmental Management Practices of Dutch SMEs. Journal of Business Ethics, 109(4), 411-429. https://doi.org/10.1007/s10551-011-1137-x

Wahga, A. I., Blundel, R., \& Schaefer, A. (2017). Understanding the drivers of sustainable entrepreneurial practices in Pakistan's leather industry. International Journal of Entrepreneurial Behavior \& Research, IJEBR-11-2015-0263. https:// doi.org/10.1108/IJEBR-11-2015-0263

Wattanapinyo, A., \& Mol, A. P. J. (2013). Ecological modernization and environmental policy reform in thailand: The case of food processing SMEs. Sustainable Development, 21(5), 309-323. https://doi.org/10.1002/sd.506

Williams, B. R., \& O’Donovan, G. (2015). The accountants' perspective on sustainable business practices in SMEs. Social Responsibility Journal, 11(3), 641-656. https://doi.org/10.1108/SRJ-07-2014-0096

Williams, S., \& Schaefer, A. (2013). Small and Medium-Sized Enterprises and Sustainability: Managers' Values and Engagement with Environmental and Climate Change Issues. Business Strategy and the Environment, 22(3), 173-186. https://doi.org/10.1002/bse.1740

Williamson, D., Lynch-wood, G., \& Ramsay, J. (2006). of Environmental SMEs Behaviour and the in Manufacturing Implications for CSR. Journal of Business Ethics, 67(3), 317-330. https://doi.org/10.1007/s10551-006-9187-1

Yu, J. (2007). BUILDING A SUSTAINABLE BUSINESS IN CHINA' S SMALL AND MEDIUMSIZED ENTERPRISES ( SMEs ), 9(1), 19-43.

Zhang, B., Bi, J., \& Liu, B. (2009). Drivers and barriers to engage enterprises in environmental management initiatives in Suzhou Industrial Park, China. Frontiers of Environmental Science and Engineering in China, 3(2), 210-220. https://doi.org/10.1007/s11783-009-0014-7 